\title{
Współczesna samotność człowieka ujęta w sześciu kubistycznych obrazach, czyli analiza i interpretacja wiersza Mirona Białoszewskiego ,Do NN***,
}

\author{
Anna Śledź \\ Uniwersytet Warmińsko-Mazurski \\ ul. Szrajbera 11, Olsztyn \\ anna_sledz@op.pl \\ Do $N N^{* * *}$ \\ nagle \\ wycinasz sie \\ z pomieszanych form ulicy wypukłościq nóg \\ zbliżasz się-pót \\ mijam cię pót \\ jakże mi szkoda \\ tej zawsze jednej strony nie widzianej! \\ odchodzisz —pót \\ ruch innych \\ kroi cie \\ w coraz drobniejsze \\ kawatki
}

\begin{abstract}
Samotność, o ile nas przeraża, o tyle stanowi nieuniknioną część naszego człowieczeństwa, dając zbyt wiele, by można to było ogarnąc ludzkim rozumem. Boimy się samotności, bo stawia ona człowieka sam na sam z jego duszą bez możliwości wsparcia $\mathrm{z}$ zewnątrz. Jakże więc często, patrząc duszy w oczy, unikamy odpowiedzialności za swoje życie i uciekamy w thum, by tylko wznieść wysoko dłoń i niemym krzykiem błagać o obecność drugiego człowieka, który materialnie stanąłby w miejscu naszej wewnętrznej niedoskonałości. Jednak bardzo niewielu jest takich, którzy odpowiedzą na to właśnie. Częściej jest tak, że po prostu się mijamy — na ulicy, w pracy, wśród bliskich. Zatraciliśmy zdolność spontanicznego kontaktu z drugim człowiekiem. Cierpiąc więc na brak uczuć, od razu żądamy miłości i w konsekwencji tracimy możliwość porozumienia, wciąż podtrzymując swe odosobnienie. Samotni końca XX wieku to samotni skazani na bierność - nie krzyczący i nie błagający, lecz snujący się po ulicach miasta, przenikający przez tłum przenikających — to ludzie non noti.
\end{abstract}

„Do NN***” Mirona Białoszewskiego to poetyckie przedstawienie sytuacji-symbolu, czyli wspomnianego już thumu przenikających się istot ludzkich. Nie ma tu jednak spodziewanego hałasu, gwaru charakterystycznego dla miasta. Brak brzmieniowych środków stylistycznych dotyczących tła zdarzenia jest spowodowane zatrzymaniem zdarzenia w czasie (liczy się tylko ta 
sytuacja, możliwość podjęcia kontaktu z drugą osobą). Jedyna ekspresja całego wiersza to wyraz nagle, ale i ten można podważyć, biorąc pod uwagę efekt kadrów - czytając bowiem wiersz doznaje się uczucia oglądania obrazów - sześciu zamkniętych cyklem przedstawień. Jeżeli więc pierwszego domyślimy się (to thum na ulicach miasta), to owo nagle staje się tylko biernym elementem świata przedstawionego. Każdy następny obraz jest uzupełnieniem następnego, $\mathrm{z}$ przesunięciem kamery o $180^{\circ}$ : na drugim za rogiem pojawia się osoba, która na trzecim wychodzi naprzeciw ,ja” lirycznemu, by przejść obok i zniknąc w thumie - wszystko to odbywa się w ruchu pionowym w stosunku do podmiotu lirycznego. Malarska wyobraźnia i precyzja słów Białoszewskiego sugerują, że owe obrazy malowane są w konwencji kubistycznej:

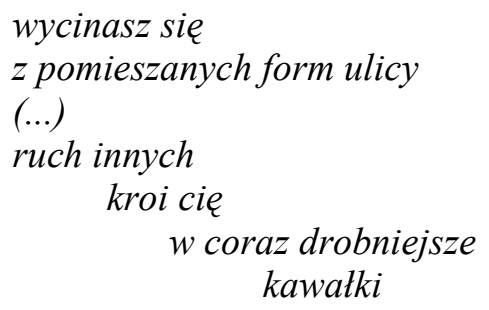

Kubizm i warstwa leksykalna wiersza pt. Do $\mathrm{NN}^{* * *}$ kreują człowieka zdepersonalizowanego, uwikłanego $\mathrm{w}$ reizm. Szczególną rolę pełnią tu czasowniki wycinasz się i kroi, które uprzedmiatawiają osobę obserwowaną i relacja między nią a podmiotem lirycznym staje się relacją ,ja - rzecz” lub „rzecz - rzecz”, co jest konsekwencją alienacji człowieka w bezosobowy thum. Osoba jest częścią pomieszanych form ulicy na zasadzie równy $\mathrm{z}$ równym - w tej sytuacji jednostkom trudno odnaleźć siebie nawzajem. Dlatego nie zostaje wszczęty dialog, a jedynym śladem dostrzeżenia problemu jest żal podmiotu lirycznego:

\section{jakże mi szkoda}

tej zawsze jednej strony nie widzianej!

Ludzka samotność powoduje, że zwykły kontakt już nie wystarcza. Oprócz zawsze widzianych tylko „połówek” osoby, chciałoby się objąć wzrokiem ją całą. Wyrażony jest tu głód emocjonalny - głód osoby (nie rzeczy), który może być zaspokojony tylko skonsumowanym związkiem w relacji ,ja-ja”. Ale osoba- rzecz odchodzi, a

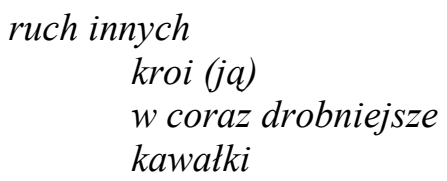

czyli, mówiąc po prostu, znika w tłumie. Nie została nawet podjęta próba porozumienia. Podmiot liryczny w ten sposób uprzedmiotowił również siebie, dawszy dowód, że i on jest tylko częścią bezosobowego społeczeństwa.

$\mathrm{W}$ wierszu Do $\mathrm{NN}^{* * *}$ pojawia się również problem związku z tradycja literacką. Białoszewski, uciekając od konwencjonalnej poetyckości, odrzuca rozlewność, patetyczność, a w ich miejsce wbudowuje formę wiesza białego zwięzłymi słowami doprowadzonymi do perfekcji swoich znaczeń. Pozbawione ozdobników mówią tylko sobą zawężając się jedynie przez wzajemne zestawienia. Eliptycznie zbudowane zdania:

$$
\begin{aligned}
& \text { zbliżasz się-pót } \\
& \text { mijam cię-pót } \\
& \text { (...) } \\
& \text { odchodzisz-pót }
\end{aligned}
$$


łatwo można odczytać, gdy dodamy domyślne „widzę (pół) osoby”. Ten środek stylistyczny pełni rolę odwrotną do przypisanej - nie dynamizuje akcji, lecz tworzy statyczny tok wiersza. Podobnie jest $\mathrm{z}$ metaforami: wycinasz się $z$ pomieszanych form ulicy i ruch innych kroi cię $w$ coraz drobniejsze kawatki.

Wieloznaczną interpretację narzuca tytuł Do NN***. Będąc kontynuacją tradycji literackiej w adresowaniu utworów do konkretnych osób (np. Do Jana J. Kochanowskiego, Do Laury, Do DD A. Mickiewicza, Do Marka Aurelego Z. Herberta), wiersz może być adresowany do takiej NN. Jednak treść utworu sugeruje, że owo NN to Non Notus, czyli symbol oznaczający człowieka nieznanego, który nie jest tu kimkolwiek, lecz człowiekiem samotnym, jak mawiał Stachura, „w zbroi, jak naturalna kolczuga". On i NN wzajemnie się implikują, tworząc nierozerwalnie obraz osoby, która jest rzeczą. Dotyczy to jednak formy zewnętrznej, bo w środku człowiek zawsze skrywa duszę, określające go jestestwo, o czym wiersz Do NN* nie mówi wprost, a co nie trudno wkomponować w jego treść, bo samotność o ile nas przeraża, o tyle stanowi nieuniknioną część naszego człowieczeństwa. Czasem tylko za bardzo nas ogarnia, byśmy byli w stanie wyrzec zwykłe słowo. 